\title{
The vulnerability of calretinin-containing hippocampal interneurons to temporal lobe epilepsy
}

\author{
Kinga Tóth ${ }^{1,2}$ and Zsófia Maglóczky ${ }^{2}$ \\ 1 Institute of Cognitive Neuroscience and Psychology, Research Centre for Natural Sciences, Hungarian Academy of Sciences, Budapest, Hungary \\ 2 Institute of Experimental Medicine, Hungarian Academy of Sciences, Budapest, Hungary
}

\author{
Edited by: \\ Filip Barinka, University of \\ Regensburg, Germany \\ Reviewed by: \\ James C. Vickers, University of \\ Tasmania, Australia \\ Gundela Meyer, Universidad de La \\ Laguna, Spain \\ *Correspondence: \\ Zsófia Maglóczky, Institute of \\ Experimental Medicine, Hungarian \\ Academy of Sciences, Szigony \\ Street 43, Budapest 1083, Hungary \\ e-mail:magloczky.zsofia@ \\ koki.mta.hu
}

This review focuses on the vulnerability of a special interneuron type-the calretinin (CR)-containing interneurons-in temporal lobe epilepsy (TLE). CR is a calcium-binding protein expressed mainly by GABAergic interneurons in the hippocampus. Despite their morphological heterogeneity, CR-containing interneurons form a distinct subpopulation of inhibitory cells, innervating other interneurons in rodents and to some extent principal cells in the human. Their dendrites are strongly connected by zona adherentiae and presumably by gap junctions both in rats and humans. CR-containing interneurons are suggested to play a key role in the hippocampal inhibitory network, since they can effectively synchronize dendritic inhibitory interneurons. The sensitivity of CR-expressing interneurons to epilepsy was discussed in several reports, both in animal models and in humans. In the sclerotic hippocampus the density of CR-immunopositive cells is decreased significantly. In the non-sclerotic hippocampus, the CR-containing interneurons are preserved, but their dendritic tree is varicose, segmented, and zona-adherentia-type contacts can be less frequently observed among dendrites. Therefore, the dendritic inhibition of pyramidal cells may be less effective in TLE. This can be partially explained by the impairment of the CR-containing interneuron ensemble in the epileptic hippocampus, which may result in an asynchronous and thus less effective dendritic inhibition of the principal cells. This phenomenon, together with the sprouting of excitatory pathway axons and enhanced innervation of principal cells, may be involved in seizure generation. Preventing the loss of CR-positive cells and preserving the integrity of CR-positive dendrite gap junctions may have antiepileptic effects, maintaining proper inhibitory function and helping to protect principal cells in epilepsy.

Keywords: calretinin, interneuron, dendritic inhibition, synchronization, epilepsy

\section{INTRODUCTION}

Calretinin (CR) is a calcium-bindig protein, belonging to the calmodulin superfamily, which was shown to be present in many brain regions (Rogers, 1987; Faas et al., 2007).

In the rodent hippocampus the majority of the CR-positive cells seem to be GABAergic interneurons (Jacobowitz and Winsky, 1991; Miettinen et al., 1992; Liu et al., 1996).

They represent a distinct subpopulation of interneurons (Gulyás et al., 1992; Liu et al., 1996) with a negligible overlap with other calcium binding protein-containing interneuronsparvalbumin and calbindin - in rat and monkey (Miettinen et al., 1992; Rogers and Resibois, 1992; Seress et al., 1993b).

Interneurons of the hippocampus can be divided into three main functional groups according to their role in the neuronal network (Freund and Buzsáki, 1996). Perisomatic inhibitory cells innervate the soma, axon initial segment or proximal dendrites of principal cells (basket and axo-axonic cells) (Handelmann et al.,

Abbreviations: CA 1, 2, 3, regions of the Cornu Ammonis according to Lorente de No; CR, calretinin; TLE, temporal lobe epilepsy.
1981; Emson et al., 1982; Somogyi et al., 1983; Kosaka et al., 1985, 1987; Katsumaru et al., 1988; Seress et al., 1991, 1993a; Li et al., 1992; Ribak et al., 1993; Halasy et al., 1996) and control the output of principal cells (Arai et al., 1995; Freund and Buzsáki, 1996; Miles et al., 1996; Holmes and Levy, 1997). Dendritic inhibitory cells innervate the distal dendrites of principal cells (Kawaguchi and Hama, 1988; Gulyás et al., 1993; Han et al., 1993; Buhl et al., 1994; Sik et al., 1994, 1995, 1997; Buckmaster and Schwartzkroin, 1995; Halasy et al., 1996) and control the generation of dendritic calcium spikes and synaptic plasticity (Freund and Buzsáki, 1996; Miles et al., 1996). The interneuronselective inhibitory cells innervate other interneurons, and thus have a role in the synchronization of dendritic inhibition (Acsády et al., 1996; Gulyás et al., 1996; Hajos et al., 1996; Urbán et al., 2002).

The different vulnerability of interneurons in temporal lobe epilepsy (TLE) was shown in numerous animal models and human patients (Babb et al., 1989; Houser, 1991; Sloviter, 1999; Ben-Ari and Cossart, 2000; Bouilleret et al., 2000; André et al., 2001; Ben-Ari, 2001; Arellano et al., 2004; Ben-Ari and Holmes, 
2005; Kuruba et al., 2011; Marx et al., 2013). In most studies, the relative preservation of the inhibitory input to the perisomatic domain of principal cells was described, whereas dendritic inhibition was found to be decreased (Cossart et al., 2001; Sundstrom et al., 2001; Wittner et al., 2001, 2005; Maglóczky and Freund, 2005; Tyan et al., 2014). The third functional type of interneurons are specialized to innervate other interneurons (Freund and Buzsáki, 1996; Gulyás et al., 1996) and contain VIP or CR (Acsády et al., 1996; Gulyás et al., 1996). These neurons are in an ideal position to regulate dendritic inhibition (Gulyás et al., 1996; Hajos et al., 1996; Chamberland et al., 2010; Tyan et al., 2014) and compensate the synchronizing effect of perisomatic inhibition (Cossart et al., 2001; Maglóczky and Freund, 2005), and therefore they may have a critic role in maintaining the normal network activity and may prevent synchronous discharges leading to epileptic seizures.

In this review we focus on the fate of this special interneuron type-the CR-containing interneurons-in TLE.

\section{CR-CONTAINING CELLS IN THE RODENT HIPPOCAMPUS}

Two types of CR-positive cells were found in the rat hippocampus (Gulyás et al., 1992), spiny and spine-free dendritic cells. The spine-free type can be observed in all subregions, and have a small cell body with smooth dendrites running through several layers. Their dendrites are often attached to each other over long segments. At the electron microscopic level, several puncta adherentiae were observed among contacting CR-positive dendrites (Gulyás et al., 1992, 1996). The other, spiny type is found exclusively in the hilus of the dentate gyrus and in the stratum lucidum of the CA3 region. Their dendrites run horizontally and are covered with spines. They receive the majority of their inputs from mossy fibers (Gulyás et al., 1992). Miettinen and colleagues have shown that the majority of the former type belonged to GABAergic interneurons, whereas the latter, spiny type was mainly GABA-negative (Miettinen et al., 1992).

Hippocampal CR-positive cells of the mouse are similar to the rat. However, there are species-specific differences among human/rat and mouse hippocampal areas, i.e., young granule cells and mossy cells are CR-positive in mice, whereas they are CR-negative in rats and humans (Liu et al., 1996; Blasco-Ibáñez and Freund, 1997; Fujise et al., 1998; Murakawa and Kosaka, 1999; Mátyás et al., 2004; Seress et al., 2008). However, the main interneuron types, e.g., the bipolar or bitufted, rarely spiny cells with dendrodendritic connections, are present both in rodents and humans in hippocampal areas (Gulyás et al., 1992; Nitsch and Ohm, 1995; Urbán et al., 2002). This cell type is thought to be responsible for the inhibition of other interneurons (Gulyás et al., 1996). It is well preserved throughout evolution, and therefore its role can be studied in rodent models of epilepsy.

\section{CR-CONTAINING CELLS IN THE HUMAN HIPPOCAMPUS}

In the adult human hippocampus, CR is expressed by nonprincipal cells (Nitsch and Ohm, 1995; Urbán et al., 2002). Besides the interneurons, there are a few remaining Cajal-Retzius cells at the border of stratum moleculare and stratum lacunosum-moleculare that also show CR-immunoreactivity (Abraham and Meyer, 2003). Unlike in mice and to some extent in non-human primates, mossy cells of the human dentate gyrus are negative for CR-immunostaining (Maglóczky et al., 2000; Seress et al., 2008).

The distribution of the CR-positive elements shows the typical distribution of a non-perisomatic inhibitory interneuron type. They are abundant in the stratum radiatum and at the border of lacunosum-moleculare in the Cornu Ammonis and in the hilus of the dentate gyrus (Figures 1, 2; Nitsch and Ohm, 1995; Maglóczky et al., 2000; Urbán et al., 2002).

The human CR-containing interneurons form a morphologically heterogeneous cell population: (i) multipolar or fusiform cells in the hilus, with dendrites restricted mainly in this subregion; (ii) fusiform cells in the strata moleculare and oriens with horizontal dendrites; (iii) multipolar cells in all layers; and (iv) a group of small cells with a few short dendrites in the dentate gyrus (Nitsch and Ohm, 1995; Maglóczky et al., 2000; Urbán et al., 2002; Tóth et al., 2010).

The human CR-positive interneuron population differs somewhat from those in the rat and mouse (Murakawa and Kosaka, 1999; Mátyás et al., 2004). In human, there is an abundant group of multipolar CR-immunoreactive interneurons at the border of the CA1 stratum lacunosum-moleculare, and a group of small CR-positive cells in the dentate gyrus (Nitsch and Ohm, 1995), which are absent in the rat. In addition, the characteristic spiny CR-positive cells of the rat CA3 region (Gulyás et al., 1992) are missing in the human (Nitsch and Ohm, 1995; Urbán et al., 2002).

The dendrites of the human CR-positive interneurons are smooth or rarely spiny. Similarly to rats, long segments of CRpositive dendrites of different cells are often attached to each other, especially in the CA1 region (Figure 3; Urbán et al., 2002). Zona- or puncta adherentia-type contacts were observed between these dendrites at the electron microscopic level (Urbán et al., 2002; Tóth et al., 2010).

\section{EXTRINSIC CR-CONTAINING NETWORK}

Besides the intrinsic hippocampal GABAergic CR-system deriving from the local CR-containing inhibitory interneurons, there are extrinsic glutamatergic inputs that also contain CR. In rats, monkeys and humans, a dense CR-positive fiber network can be observed at the top of the granule cell layer in the inner third of the stratum moleculare (Gulyás et al., 1992; Nitsch and Léránth, 1993; Nitsch and Ohm, 1995). The vast majority of the CR-positive terminals here are putative excitatory terminals with a thick postsynaptic density (Gulyás et al., 1992; Maglóczky et al., 2000). This excitatory pathway was shown to be originating from the supramammillary nucleus both in rats and monkeys (Nitsch and Léránth, 1993; Maglóczky et al., 1994; Borhegyi and Leranth, 1997) and, besides the stratum moleculare, it also innervates the pyramidal layer of the CA2 region (Nitsch and Léránth, 1993; Maglóczky et al., 1994; Nitsch and Ohm, 1995). Finally, a dense CRpositive axonal network can be seen at the border of strata radiatum and lacunosum-moleculare in the CA1 region, with numerous presumably excitatory CR-positive axon terminals 

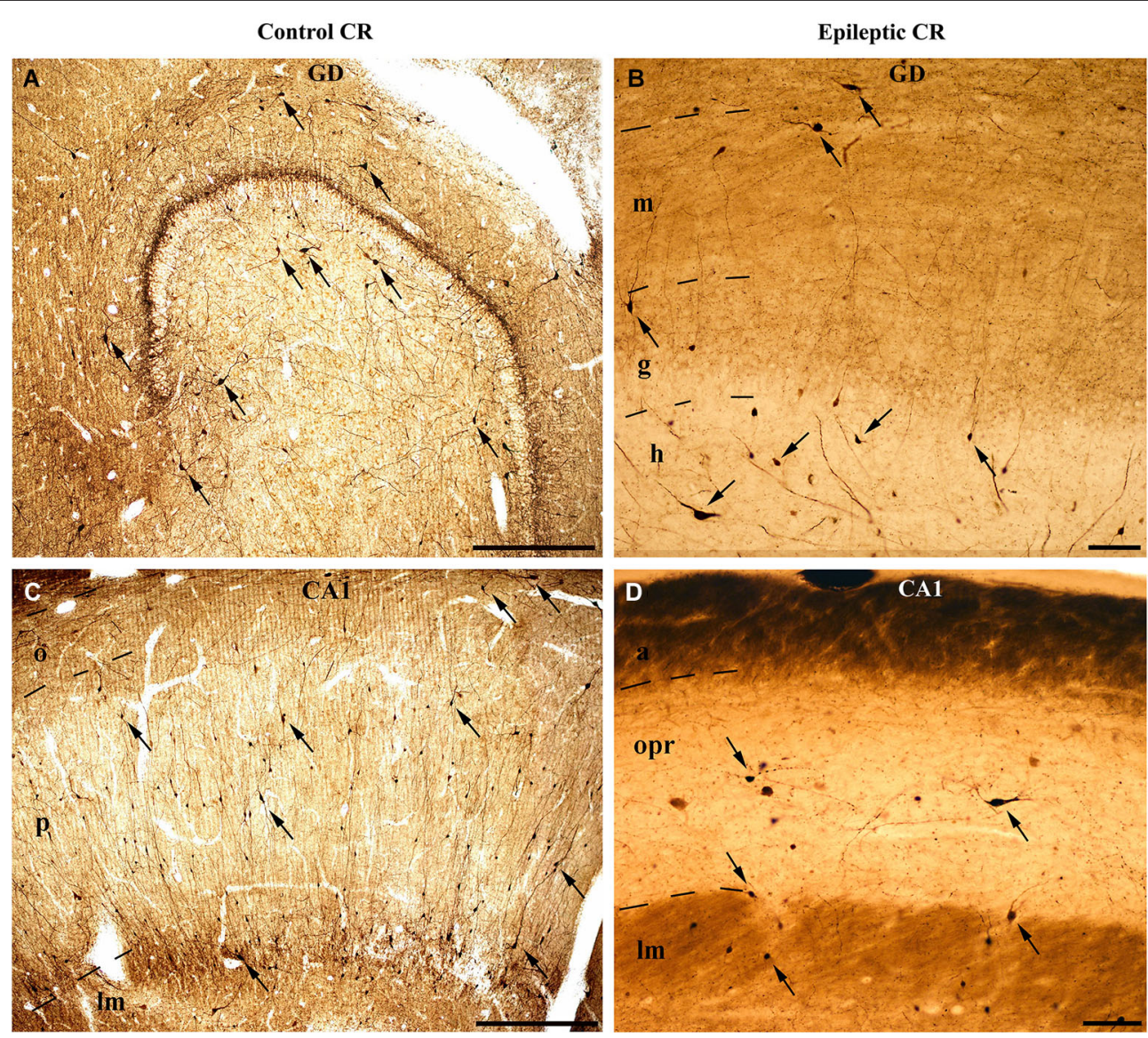

FIGURE 1 | Light micrographs show the distribution and density of CR-containing interneurons in the control $(A, C)$ and epileptic human hippocampus (B, D). CR-immunopositive cells can be observed in the entire hippocampus. (A) They are present in large numbers in the control dentate gyrus, especially in the hilus. The immunopositive cells in the outer part of the molecular layer near the hippocampal fissure are presumably Cajal-Retzius cells. (B) The epileptic dentate gyrus contains less immunopositive cells. (C) Many CR-positive interneurons can be seen in the control CA1 region, scattered throughout all layers. The largest amount of cells is present in the stratum radiatum and at the border of stratum lacunosum-moleculare. (D) The sclerotic epileptic CA1 region contains only a few CR-immunopositive interneurons with short and distorted, often segmented dendrites. GD: dentate gyrus; m: stratum moleculare; g: stratum granulosum; h: hilus; CA1 Cornu Ammonis 1; o: stratum oriens; p: stratum pyramidale; Im: stratum lacunosum-moleculare; opr: strata oriens-pyramidale-radiatum. Scales: 500 $\mu \mathrm{m}$ in (A) and (C); $100 \mu \mathrm{m}$ in (B) and (D). giving asymmetric synapses with thick postsynaptic densities (Urbán et al., 2002). In rats and monkeys, this pathway was shown to originate from the thalamic reunions nucleus (Amaral and Cowan, 1980; Fortin et al., 1996; Bokor et al., 2002; Drexel et al., 2011).

\section{FUNCTION OF CR-CONTAINING INTERNEURONS IN THE HIPPOCAMPUS}

The CR-positive interneurons are interneuron-selective inhibitory cells in the CA1 region of the rat hippocampus (Gulyás et al., 1996). Meskenaite have shown that the postsynaptic targets were partially GABAergic local circuit neurons in the monkey neocortex (Meskenaite, 1997). According to Urbán et al. a large proportion of these cells also belong to this functional type of interneuron in the human hippocampal CA1 region, innervating other $\mathrm{CR}$-containing dendrites or unstained interneuron dendrites (Urbán et al., 2002). Additionally, in humans, there is a population which innervates the dendrites of the pyramidal cells (dendritic inhibitory interneurons) (Urbán et al., 2002).

Interneuron-selective cells were suggested to be important in the synchronization of dendritic inhibitory cells (Gulyás et al., 1996; Maglóczky and Freund, 2005; Chamberland et al., 2010; Tyan et al., 2014). This is supported by the fact that: (i) their dendrites are strongly connected by zona adherentiae and possibly by gap junctions in rats (Gulyás et al., 1992, 1993), which allows the synchronous activation of the connected cell population (Galarreta and Hestrin, 1999; Gibson et al., 1999); (ii) their dendrites often run parallel with each other in the human CA1 region, forming close contacts; additionally, zona adherentiae were identified in these segments at the electron microscopic level (Urbán et al., 2002), which is a characteristic structure to support the development of gap junctions (Kosaka and Hama, 1985); and (iii) the calbindin-containing dendritic inhibitory 
interneurons are innervated by CR-positive inhibitory cells in both rats and humans (Figure 4; Gulyás et al., 1996; Tóth et al., 2010).

Dendritic inhibitory interneurons innervate the distal dendritic tree of pyramidal cells. The synchronization of dendritic inhibitory cells is a crucial process to provide an effective inhibitory control of excitatory synaptic input of pyramidal cell dendrites (Miles et al., 1996; Chamberland et al., 2010; Tyan et al., 2014).

These observations suggest that CR-containing cells form a unique inhibitory cell population in the hippocampus. Despite their low number, they play a key role in hippocampal inhibitory circuits. By synchronizing the dendritic inhibitory interneurons, they can control the efficacy of excitatory inputs to pyramidal cells (Maglóczky and Freund, 2005; Tyan et al., 2014). Therefore, studying their fate in different brain disorders, especially in epilepsy, is of special interest.

\section{CHANGES IN THE NUMBER AND DISTRIBUTION OF CR-POSITIVE INTERNEURONS IN THE HUMAN EPILEPTIC HIPPOCAMPUS}

The sensitivity of CR-expressing cells to epilepsy was discussed in several reports, both in animal models and in humans (Maglóczky and Freund, 2005; Barinka and Druga, 2010; Tóth et al., 2010). CR-containing cells were also found to be sensitive in focal cortical dysplasias (Barinka et al., 2010).

However, the published data on the sensitivity of human CRcontaining cells in epilepsy is controversial. According to Blümcke et al. the CR-containing cells are preserved in epilepsy (Blümcke et al., 1996); moreover, the number of CR-positive Cajal-Retzius cells is even increased (Blümcke et al., 1999; Thom et al., 2002). However, our group observed increased vulnerability of CRpositive cells in human TLE, including the CR-positive CajalRetzius cells (Figure 1; Maglóczky et al., 2000; Tóth et al., 2010).

The contradiction possibly emerged from the sensitivity of CRimmunostaining to the length of the post mortem delay of the applied control samples (Figure 2). The post mortem delay in the studies of Blümcke et al. varied between $6 \mathrm{~h}$ and up to 3 days (Blümcke et al., 1996, 1999). In our studies, post mortem delays for control samples were between 2-4 h (Maglóczky et al., 2000; Tóth et al., 2010). According to Urbán et al. the age of the subject, the post mortem delay and the fixation procedure has an extreme impact on the quality and quantity of CRimmunostaining (Urbán et al., 2002). The preservation of the immersion-fixed control samples with short post mortem delays was comparable to the perfusion-fixed animal tissue and immediately fixed epileptic samples (Tóth et al., 2010).

According to our results, the number of CR-containing cells decreased significantly, both in the dentate gyrus (especially in the hilus) (Maglóczky et al., 2000; Tóth et al., 2010) and in the sclerotic CA1 region (Figures 1, 2; Tóth et al., 2010). The density of the presumably persisting CR-positive Cajal-Retzius cells (Abraham and Meyer, 2003) at the border of the stratum moleculare and hippocampal fissure was also significantly reduced (Haas et al., 2002; Tóth et al., 2010), even in the non-sclerotic samples (Tóth et al., 2010).
In addition, the preserved cells had an altered morphology, suggesting the degeneration of their dendritic tree (Maglóczky et al., 2000; Tóth et al., 2010; Figure 3). In the non-sclerotic epileptic CA1 region, the number of CRpositive cells was unchanged. However, their dendrites were varicose, and contacts between the CR-positive dendrites were less frequently seen (Tóth et al., 2010; Figure 3). Consistently, zona adherentia-type contacts were rarely observed between CR-positive dendritic profiles at the electron microscopic level (Tóth et al., 2010), decreasing the possibility of the establishment and maintenance of gap junctions (Fukuda and Kosaka, 2000).

Thus, the synchronous activation of these interneuronselective inhibitory cells is possibly impaired in the human epileptic hippocampus. As part of the CR-containing cells are dendritic inhibitory interneurons in humans, this means that by losing their zona adherentia-type dendro-dendritic contacts, the CR-positive population of dendritic inhibitory cells also loses the ability to function synchronously.

\section{SYNAPTIC REORGANIZATION OF CR-POSITIVE INTERNEURONS IN THE HUMAN EPILEPTIC DG AND CA1}

Electron microscopic examinations revealed that the CRcontaining interneuronal (inhibitory) synaptic network is also changed in the epileptic human samples.

Despite the sensitivity and loss of CR-containing interneurons in the DG (Maglóczky et al., 2000; Tóth et al., 2010), an increased frequency of CR-positive interneuronal terminals was found in epilepsy (Maglóczky et al., 2000). Dentate granule cells receive an excess excitation in epilepsy due to mossy fiber sprouting (Davenport et al., 1990b; Houser et al., 1990; Represa et al., 1990; Sloviter, 1994; Mathern et al., 1995; Zhang et al., 2009). Although the increase of the frequency of CR-positive inhibitory terminals was low, regarding the severe cell loss, this might mean a sprouting of the remaining CR-containing inhibitory cells as a compensatory mechanism to offset the enhanced excitatory input on granule cell dendrites.

In controls, the majority of the CR-positive inhibitory axon terminals contacted CR-positive interneurons and pyramidal cells in the CA1 region (Figure 5; Tóth et al., 2010). In the epileptic samples, the proportion of CR-positive targets was significantly reduced. The decreased innervation of other CR-positive dendrites may reflect the impairment of the CR-containing interneuronal network. The ratio of unstained interneuron dendrites increased among the targets, whereas pyramidal cells were less frequently innervated, even in those patients where the pyramidal cells were present (nonsclerotic patients) (Figure 5; Tóth et al., 2010). The frequency of CR-positive terminals giving symmetric synapses was decreased, whereas those giving asymmetric synapses was increased in the epileptic CA1 region (Tóth et al., 2010).

Taken together, these results suggest that both synaptic and dendro-dendritic contacts of CR-positive interneurons are impaired even in the non-sclerotic epileptic human hippocampi, in the absence of any major principal cell- and CR-containing interneuron loss (Tóth et al., 2010). 
Control post mortem $2 \mathrm{~h}$

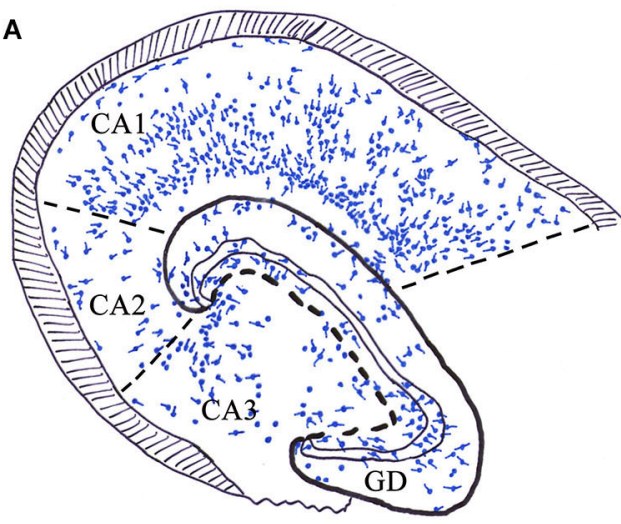

Epileptic non-sclerotic

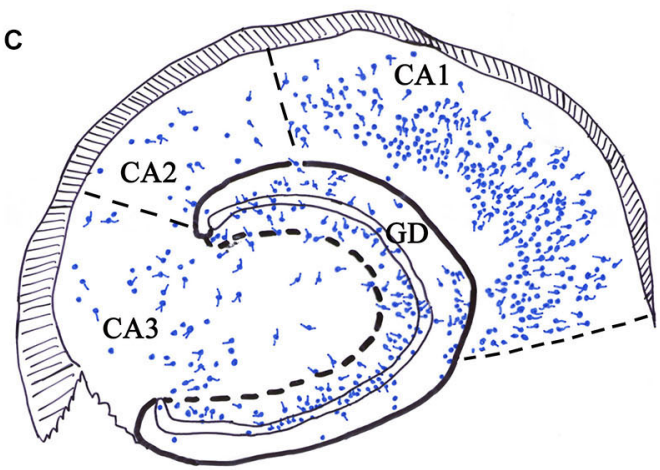

Control post mortem $8 \mathrm{~h}$

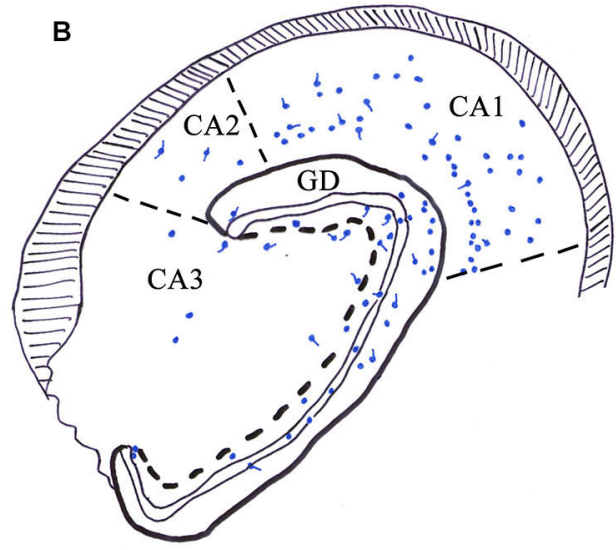

Epileptic sclerotic

D

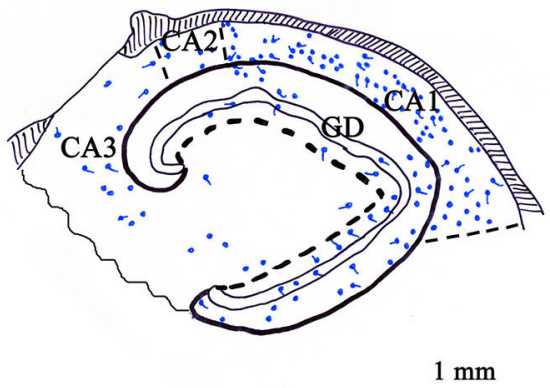

FIGURE 2 | Camera lucida drawings show the number and distribution of CR-immunoreactive cells in control human hippocampi with different post mortem delay (A, B) and in epileptic human hippocampi with different degrees of principal cell death (C, D). CR-containing cells were present in all regions of the hippocampus (A). Their number was significantly reduced in control samples with long post mortem delay (B) and in the sclerotic epileptic cases (D). In the non-sclerotic tissues (C) the number and distribution of

CR-immunoreactive cells were similar to the control, with short post mortem delay (A). The volume of the sclerotic hippocampi is reduced because of the shrinkage of the CA1 region due to the loss of CA1 pyramidal cells (D). GD: dentate gyrus; Scale: $1 \mathrm{~mm}$.

\section{CHANGES TO THE EXTRINSIC CR-CONTAINING SYSTEM IN HUMAN EPILEPTIC HIPPOCAMPUS}

Besides the changes affecting the intrinsic CR-containing system, the extrinsic CR-expressing pathways also show alterations. In the epileptic dentate gyrus, the CR-containing excitatory pathwayoriginating from the supramammillary nucleus-is expanded to the outer two thirds of the molecular layer (Figure 3; Maglóczky et al., 2000). This observation was confirmed at the electron microscopic level: whereas in controls the majority of the CRpositive excitatory terminals were located in the inner molecular layer, the frequency of terminals was similar in the inner and outer moleculare in the epileptic cases (Maglóczky et al., 2000). The extension of the supramammillary pathway was independent from the granule cell dispersion, as it occurred in all the subjects examined. The relative increase of the frequency of CR-positive terminals giving asymmetric synapses in the CA1 region could also reflect the sprouting of an excitatory pathway originating presumably from the thalamus (Amaral and Cowan, 1980; Bokor et al., 2002).

\section{EPILEPSY MODELS AND THE FATE OF CR-CONTAINING INTERNEURONS}

Numerous models of epilepsy were developed to study the mechanisms of seizures and epilepsy including genetic models, in vitro slice models, in vivo induced seizures, acquired focal models etc. (Pitkanen et al., 2006). In most cases rodents were used for in vivo chronic models, and the cortical and hippocampal areas were especially studied.

The pathological changes of the brain were classified and the sensitivity of neurons was monitored in most models. It was shown that GABAergic cells are more preserved than principal cells (Babb et al., 1989; Davenport et al., 1990a; Houser, 1991; Ben-Ari, 2001; Ben-Ari and Holmes, 2005). However, certain neurochemically identified groups of interneurons proved to be 

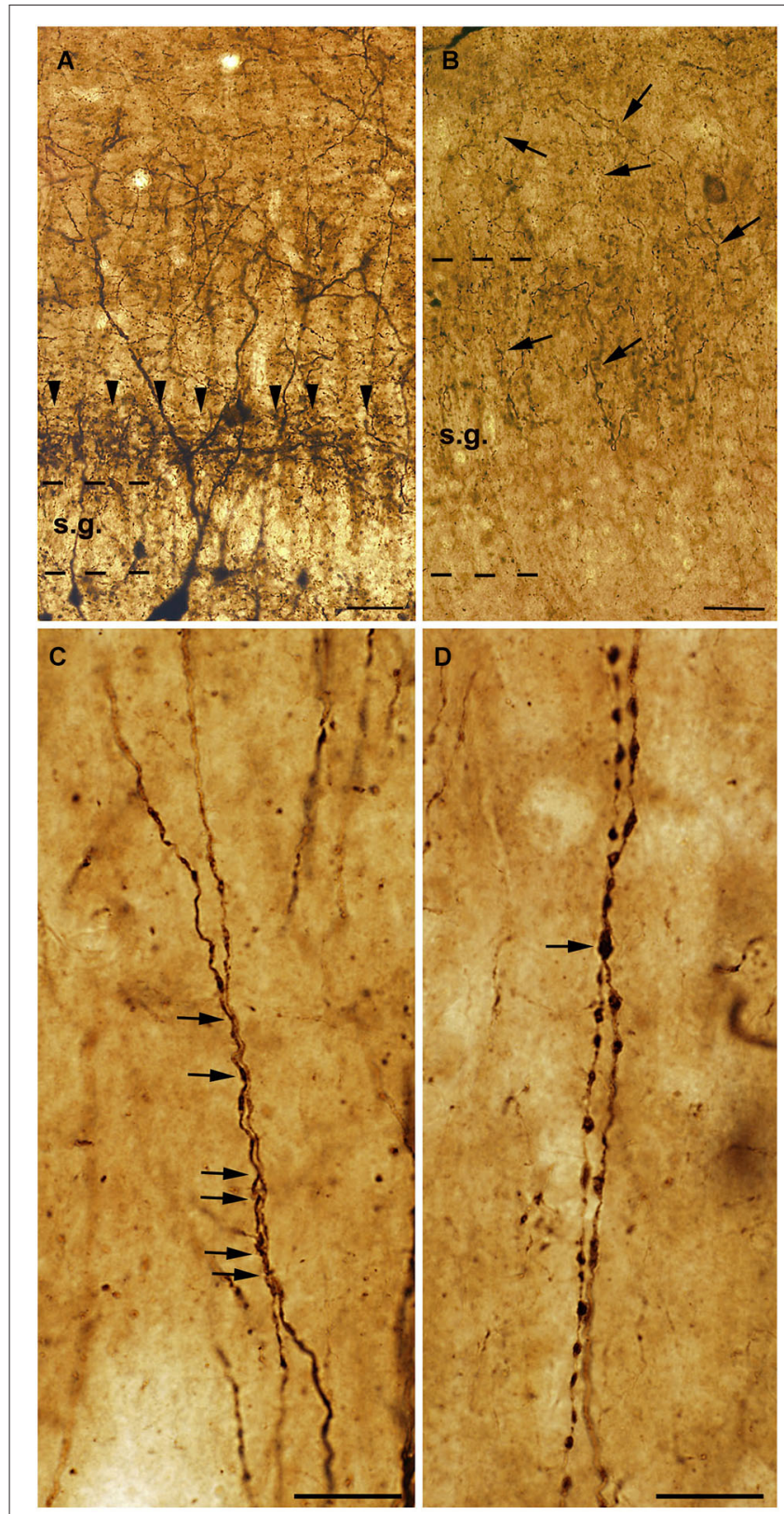

FIGURE 3 | High power light micrographs from control and epileptic samples showing the morphology of CR-positive interneuron

dendrites. Many CR-positive interneurons are located in the hilus of the control dentate gyrus (A). They usually have long and smooth dendrites arborizing densely in the stratum moleculare. In the inner molecular layer a dense network of CR-positive axon terminals can be observed, which presumably originate from the supramammillary nucleus (A, arrowheads). In the sclerotic epileptic gyrus dentatus (B) most of the CR cells disappear and the CR-positive supramammillary input extends to the entire stratum moleculare (B, arrows). The dispersion of the granule cell layer can also be observed in many epileptic cases. In the control CA1 region (C), dendrites of CR-positive interneurons are usually long, smooth and vertically oriented. They are often juxtaposed and run together over short segments (C, arrows). However, in the non-sclerotic samples (D) the dendrites are varicose and the contacts between CR-positive interneuron dendrites are less frequent than in controls (D, arrow). s.g.: stratum granulosum; Scales: (A, B): $50 \mu \mathrm{m}$; (C, D): $20 \mu \mathrm{m}$
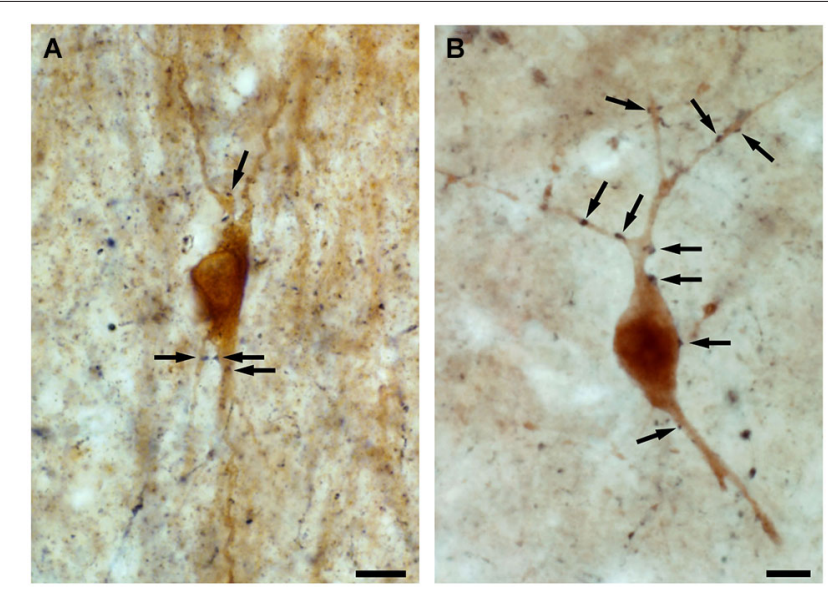

FIGURE 4 | High power light micrographs showing the innervation of calbindin-containing interneurons by CR-positive fibres. By double immunolabeling experiments, applying DAB and DAB-Ni as chromogens, we show that both in the control $(A)$ and in the epileptic $(B)$ human CA1 region, the axon terminals of the $\mathrm{CR}$-containing interneurons (black reaction product) innervate the calbindin-containing interneurons (brown reaction product) (arrows). Scale: $10 \mu \mathrm{m}$.

sensitive to epileptic injury, like somatostatin cells in TLE (de Lanerolle et al., 1989; Mitchell et al., 1995; Sundstrom et al., 2001). Interestingly, as compared to other GABAergic interneurons, the fate of CR-containing interneurons was less examined in epilepsy.

Hippocampal CR-positive cells were shown to be vulnerable to excitotoxic cell damage in ischaemia (Freund and Maglóczky, 1993) and in various models of epilepsy (Figure 6; Magloczky and Freund, 1993; Maglóczky and Freund, 1995; Ben-Ari and Cossart, 2000; Bouilleret et al., 2000; André et al., 2001; Domínguez et al., 2003; Slézia et al., 2004; van Vliet et al., 2004; Cobos et al., 2005; Tang et al., 2006; Wu et al., 2012; Huusko et al., 2013).

\section{SIMILARITY TO HUMAN TLE}

For a detailed comparison to human TLE, data from chronic models of TLE concerning the CR-positive interneurons is summarized here. These models usually show remarkable similarity to human hippocampal pathology in TLE (Sloviter, 1996; Bernard et al., 1998; Ben-Ari, 2001; Sharma et al., 2007; Curia et al., 2008; Tang and Loke, 2010; Carriero et al., 2012), including sclerosis, loss of pyramidal cells in the CA1 and CA3c regions, hilar interneuronal loss, and the preservation of calbindincontaining interneurons (Sloviter et al., 1991; Wittner et al., 2002).

Reduction in the number of CR-containing cells was found in the hippocampus after electrical induction of status epilepticus (van Vliet et al., 2004), in traumatic brain injury (Huusko et al., 2013), in a kainate model of TLE (Figure 6; Magloczky and Freund, 1993; Maglóczky and Freund, 1995) and in the pilocarpine model of epilepsy (André et al., 2001; Tang et al., 2006; Zhang et al., 2009; Wu et al., 2012). CR-positive cells showed sensitivity for single status epilepticus without recurrent seizure (Fabene et al., 2001). 


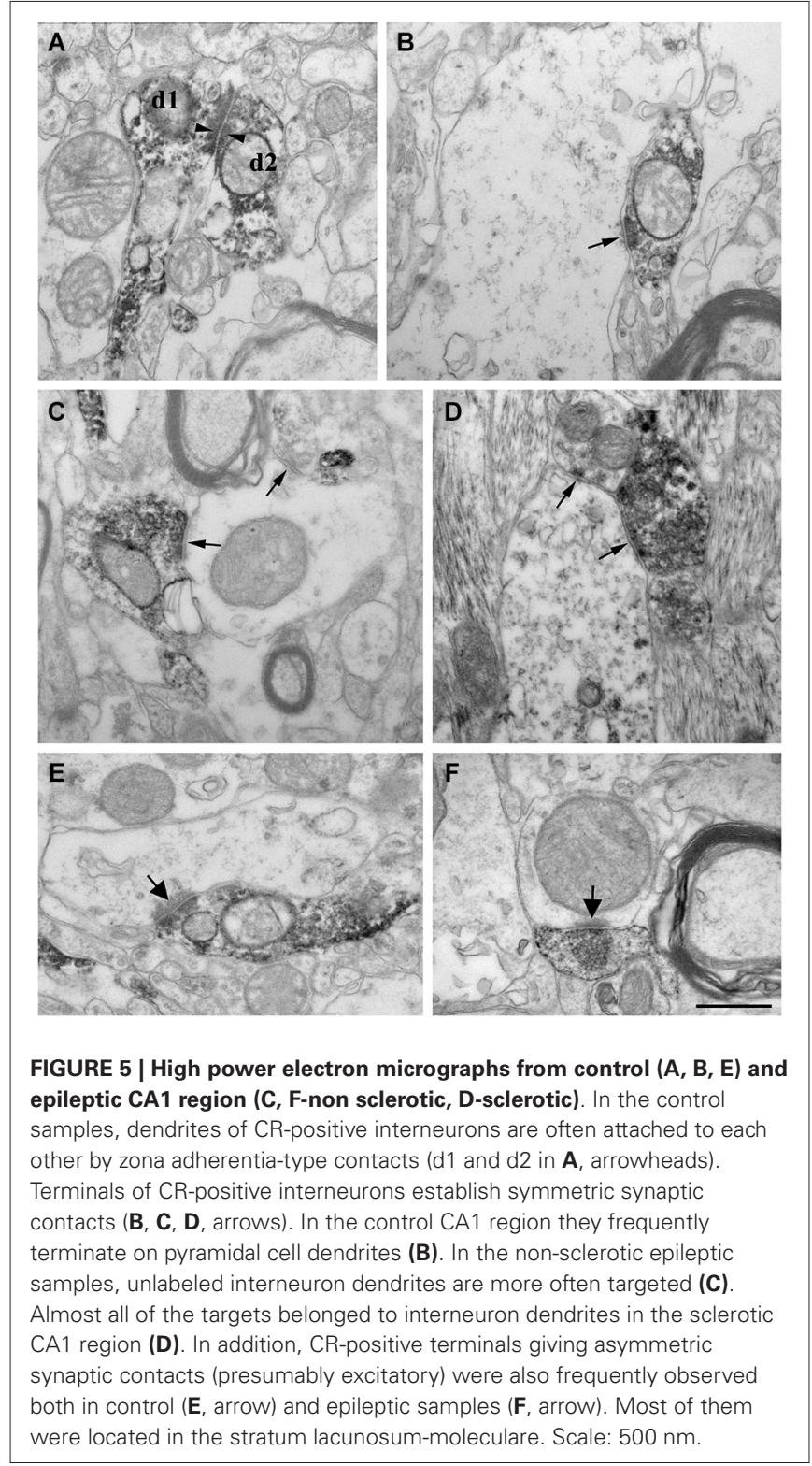

Although CR-immonopositive interneurons are morphologically and functionally different (Gulyás et al., 1992), no selective loss of a certain morphological type was found in the models of epilepsy. The spiny CR-positive cells in the stratum lucidum of CA3 regions showed profound sensitivity, as they die both in ischaemia (Freund and Maglóczky, 1993) and epilepsy (Magloczky and Freund, 1993; Maglóczky and Freund, 1995; André et al., 2001; Domínguez et al., 2003; Zhang et al., 2009) presumably due to their strong mossy fiber input, which is further enhanced in epilepsy. The bipolar cellspresumably responsible for interneuron specific inhibition-are also strongly decreased in number, and their dendritic tree is reduced in size and shows segmentation in epileptic hippocampi (Figure 6; Magloczky and Freund, 1993; Slézia et al., 2004; Zhang et al., 2009), similarly to that found in human TLE (Tóth et al., 2010). Besides synaptic contacts, CR-immunopositive cells
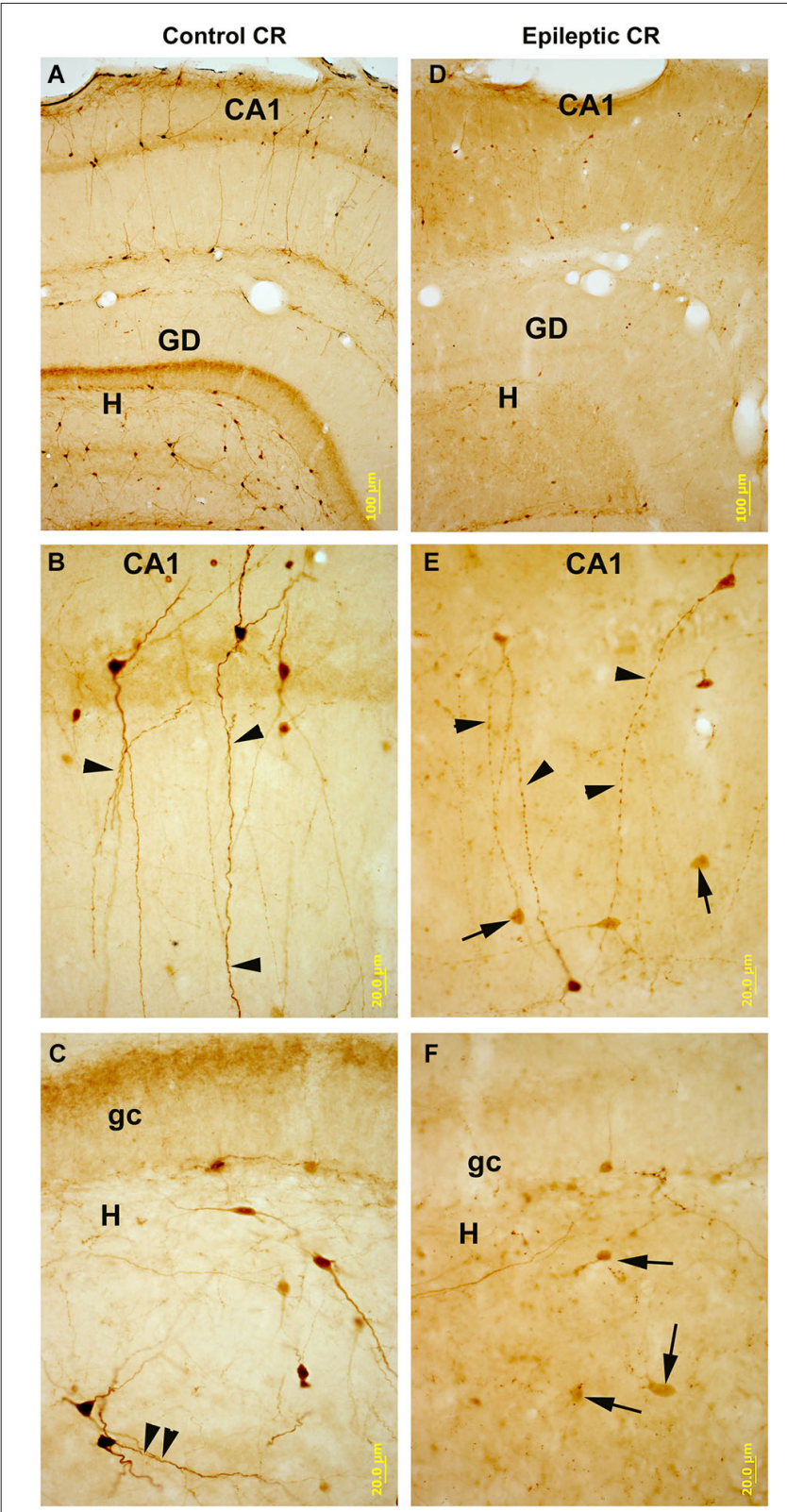

FIGURE 6 | CR-immunostained sections of hippocampal subfields in control and kainate-treated epileptic rats after one weak survival time. In control (A-C) CR-containing interneurons are numerous in all subfields of the hippocampus. They are heterogeneous in shape and localization (panel A), they posses smooth or sparsely spiny dendrites. In the CA1 region bipolar cells are dominant with long, parallel running dendrites (panel B). Arrowheads point to the dendritic contacts. In the hilus $(H)$ of the dentate gyrus (DG, panel C) they are mostly multipolar cells, and parallel running dendrites are also present here (arrowheads). In the hippocampi of the kainate-treated rats (D-F) the number of CR-containing cells is profoundly decreased in all subfields. In CA1 (panel E) the surviving cells have segmented, varicose dendrites (arrowheads). In the hilus the decrease in the number of cells is more severe than in the CA1. Arrows point to the dying, faint cells with reduced/absent dendritic tree. DG: dentate gyrus; gc: granule cell layer; H: hilus. Scales: (A,D): 100 um; (B-F): 20 um.

are also connected by their dendritic tree (Figure 6; Gulyás et al., 1992), and therefore the disruption of the dendritic 
connections may cause dysfunction of these cells in rodent models.

Interestingly, even a small dose of kainate (Maglóczky and Freund, 1995) may cause reduction in the number of CRcontaining cells, especially in the hilus, suggesting that hilar CRpositive interneurons may be more sensitive than neurons in other subfields (Figure 6).

Analyses of the time course of the cell loss showed that it begins soon after excitotoxic insults (Freund and Maglóczky, 1993; Maglóczky and Freund, 1995). After few hours, a significant decrease can be seen in the hilus and CA3 of the rat.

However, granule cells and mossy cells also contain CR in mice (Liu et al., 1996; Fujise et al., 1998; Mátyás et al., 2004), especially in young animals (Blasco-Ibáñez and Freund, 1997; Brandt et al., 2003). In older animals the CR-staining of the principal cells is weaker. In addition, induction of status epilepticus may transiently accelerate the production of newly formed neurons (Kralic et al., 2005), which are mostly granule cells (Hester and Danzer, 2013). Therefore, more numerous CR-positive cells might be seen in the epileptic mice after pilocarpine-induced epilepsy, their number is decreased at the chronic phase with the decreasing tendency of neuron production (Kralic et al., 2005) and weakening of the CR-immunopositivity of principal cells with time (Brandt et al., 2003).

\section{MECHANISM OF DEATH OF CR-CONTAINING NEURONS}

The exact mechanism of death of CR-containing cells is not known. According to the morphological signs (Martin, 2001), CR-containing cells die by a necrotic type of excitotoxic degeneration, not by apoptosis. Their electron microscopic examination shows degenerating cytoplasm, decaying mitochondria and numerous phagocytic vacuoles, suggesting the overproduction of abnormal proteins and energy failure (Maglóczky et al., 2000; Tóth et al., 2010).

Although these cells contain a calcium binding protein, they proved to be extremely sensitive for epileptic and ischemic conditions with large calcium ion influx. One explanation of their extreme sensitivity can be their strong connectivity with each other, as they may react to the insults as a network (Gulyás et al., 1992; Tóth et al., 2010). On the other hand, they contain thin cytoplasm and they are poor in organelles. Therefore we can assume that their energy supply is weaker and makes them vulnerable to excitotoxic stress (Hipólito-Reis et al., 2013). The increased excitability of CR-positive cells in epilepsy, caused by the upregulation of a voltage-gated $\mathrm{Na}$ channel (Kim et al., 2008) may also contribute to their vulnerability to excitotoxic insults.

\section{CONCLUSION-CONSEQUENCES OF THE VULNERABILITY OF CR-POSITIVE INTERNEURONS}

The alterations and/or sensitivity of different calcium-binding protein-containing interneurons in human TLE were discussed in several reports (Sloviter et al., 1991; Maglóczky et al., 2000; Wittner et al., 2001, 2002; van Vliet et al., 2004; Tóth et al., 2010). Calbindin-containing interneurons seem to be preserved and enlarged, and display a sprouted axonal arbor. The parvalbumincontaining cells are also preserved, although many of them most likely loose immunoreactivity for parvalbumin due to calciumoverload (Johansen et al., 1990). In contrast, CR-containing interneurons are highly sensitive. The different vulnerability of these calcium-binding protein containing interneurons probably depends on the distinct input-output properties of these cells and the intrinsic enzymatic properties, number of mithochondria etc., rather than the type of the calcium-binding protein they express. CR-containing interneurons were shown to be vulnerable in epilepsy in most published studies. Decreased cell number (Magloczky and Freund, 1993; Maglóczky and Freund, 1995; André et al., 2001; Slézia et al., 2004; van Vliet et al., 2004; Tang et al., 2006; Muzzi et al., 2009), altered dendritic tree, decreased amount of dendritic contacts between cells (Tóth et al., 2010) and a synaptic reorganization of CR-positive inhibitory terminals were described (Maglóczky et al., 2000; Tóth et al., 2010).

These results are of special interest, since dendritic inhibition was shown to be impaired in epilepsy, together with an intact perisomatic inhibition (Cossart et al., 2001). This can be only partially explained by the sensitivity of somatostatin and neuropeptide Ycontaining dendritic inhibitory interneurons (de Lanerolle et al., 1988; Mitchell et al., 1995; Sundstrom et al., 2001), since the axons of these cells show a remarkable sprouting (de Lanerolle et al., 1989; Sperk et al., 1992). In addition, the well preserved (Sloviter et al., 1991) calbindin-containing dendritic inhibitory cells also show an axonal sprouting (Wittner et al., 2002). However, despite of the sprouting of dendritic inhibitory cells, dendritic inhibition of pyramidal cells was found to be ineffective in TLE (Cossart et al., 2001; Ben-Ari and Dudek, 2010).

Taken together, these findings suggest that the sensitivity of CR containing interneurons plays an important role in the impairment of dendritic inhibition in epilepsy:

1. the synchronous activation of these interneuron-selective inhibitory cells is possibly impaired, leading to an asynchronous and less effective dendritic inhibition

2. the CR-containing population of dendritic inhibitory cells are also impaired, further decreasing the efficacy of dendritic inhibition

3. due to the changes in their synaptic target distribution, they innervate principal cell dendrites less frequently in epileptic human hippocampus

Since the impaired dendritic inhibition may cause a less effective control of the efficacy and plasticity of excitatory inputs to principal cells, and subsequently to the formation of principal cell assemblies connected by abnormally potentiated synapses, the impairment of CR-positive cells can be involved in epileptogenesis and seizure generation (Maglóczky and Freund, 2005; El-Hassar et al., 2007; Tóth et al., 2010). Furthermore, these excitatory inputs were shown to undergo sprouting both in animal models (Perez et al., 1996; Esclapez et al., 1999; Ben-Ari, 2001; Lehmann et al., 2001) and humans (Lehmann et al., 2000; Magloczky, 2010), partly explaining why severe intractable seizures can occur even in non-sclerotic patients, where the majority of principal and non-principal cells are preserved (Maglóczky and Freund, 2005; Magloczky, 2010; Tóth et al., 2010). The excessive reorganization of the hippocampal inhibitory network, the sprouting of either intrinsic or afferent excitatory pathways, together with the intact 
output from the CA1 region, may render the non-sclerotic hippocampus a potent epileptogenic region (Maglóczky and Freund, 2005; Magloczky, 2010).

The sensitivity of CR-expressing interneurons for excitotoxic insults was also shown in animal models (Magloczky and Freund, 1993; Maglóczky and Freund, 1995; André et al., 2001; Domínguez et al., 2003; Zhang et al., 2009). Since the early loss of these cells can be observed in the acute and latent phase of epileptogenesis (Zhao et al., 2008), we can hypothesize that recurrent seizure generation might be associated with a loss of a certain amount of CR-positive cells, among other factors.

Prevention of the loss of CR-positive cells and preserving the integrity of the attached CR-positive dendrites may have antiepileptic effects, protecting the proper inhibitory function and helping to spare principal cells in epilepsy (Tóth et al., 2010). Since they die by degeneration after excitotoxic insults in the acute-to-latent phases, one therapeutic possibility may be to promote their survival during the initial phase of epilepsy.

\section{ACKNOWLEDGMENTS}

The excellent technical assistance of Mrs. K. Lengyel, Mr. Gy. Goda, and Mrs. Szepne Emoke Simon is acknowledged. This study was supported by the ESF, EUROCORES programme, EuroEPINOMICS CoGIE by OTKA, Hungary (NN 102802) and KTIA_NAP-13.

\section{REFERENCES}

Abraham, H., and Meyer, G. (2003). Reelin-expressing neurons in the postnatal and adult human hippocampal formation. Hippocampus 13, 715-727. doi: 10. 1002/hipo.10125

Acsády, L., Görcs, T. J., and Freund, T. F. (1996). Different populations of vasoactive intestinal polypeptide-immunoreactive interneurons are specialized to control pyramidal cells or interneurons in the hippocampus. Neuroscience 73, 317-334. doi: 10.1016/0306-4522(95)00609-5

Amaral, D. G., and Cowan, W. M. (1980). Subcortical afferents to the hippocampal formation in the monkey. J. Comp. Neurol. 189, 573-591. doi: 10.1002/cne. 901890402

André, V., Marescaux, C., Nehlig, A., and Fritschy, J. M. (2001). Alterations of hippocampal GAbaergic system contribute to development of spontaneous recurrent seizures in the rat lithium-pilocarpine model of temporal lobe epilepsy. Hippocampus 11, 452-468. doi: 10.1002/hipo.1060.abs

Arai, A., Silberg, J., and Lynch, G. (1995). Differences in the refractory properties of two distinct inhibitory circuitries in field CA1 of the hippocampus. Brain Res. 704, 298-306. doi: 10.1016/0006-8993(95)01137-4

Arellano, J. I., Muñoz, A., Ballesteros-Yáñez, I., Sola, R. G., and DeFelipe, J. (2004). Histopathology and reorganization of chandelier cells in the human epileptic sclerotic hippocampus. Brain 127, 45-64. doi: 10.1093/brain/awh004

Babb, T. L., Pretorius, J. K., Kupfer, W. R., and Crandall, P. H. (1989). Glutamate decarboxylase-immunoreactive neurons are preserved in human epileptic hippocampus. J. Neurosci. 9, 2562-2574.

Barinka, F., and Druga, R. (2010). Calretinin expression in the mammalian neocortex: a review. Physiol. Res. 59, 665-677.

Barinka, F., Druga, R., Marusic, P., Krsek, P., and Zamecnik, J. (2010). Calretinin immunoreactivity in focal cortical dysplasias and in non-malformed epileptic cortex. Epilepsy Res. 88, 76-86. doi: 10.1016/j.eplepsyres.2009.09.021

Ben-Ari, Y. (2001). Cell death and synaptic reorganizations produced by seizures. Epilepsia 42, 5-7. doi: 10.1046/j.1528-1157.2001.042suppl.3005.x

Ben-Ari, Y., and Cossart, R. (2000). Kainate, a double agent that generates seizures: two decades of progress. Trends Neurosci. 23, 580-587. doi: 10.1016/s01662236(00)01659-3

Ben-Ari, Y., and Dudek, F. E. (2010). Primary and secondary mechanisms of epileptogenesis in the temporal lobe: there is a before and an after. Epilepsy Curr. 10, 118-125. doi: 10.1111/j.1535-7511.2010.01376.x
Ben-Ari, Y., and Holmes, G. L. (2005). The multiple facets of gamma-aminobutyric acid dysfunction in epilepsy. Curr. Opin. Neurol. 18, 141-145. doi: 10.1097/01. wco.0000162855.75391.6a

Bernard, C., Esclapez, M., Hirsch, J. C., and Ben-Ari, Y. (1998). Interneurones are not so dormant in temporal lobe epilepsy: a critical reappraisal of the dormant basket cell hypothesis. Epilepsy Res. 32, 93-103. doi: 10.1016/s09201211(98)00043-6

Blasco-Ibáñez, J. M., and Freund, T. F. (1997). Distribution, ultrastructure and connectivity of calretinin-immunoreactive mossy cells of the mouse dentate gyrus. Hippocampus 7, 307-320. doi: 10.1002/(sici) 1098-1063(1997)7:3<307::aidhipo6 > 3.0.co;2-h

Blümcke, I., Beck, H., Nitsch, R., Eickhoff, C., Scheffler, B., Celio, M. R., et al. (1996). Preservation of calretinin-immunoreactive neurons in the hippocampus of epilepsy patients with Ammon's horn sclerosis. J. Neuropathol. Exp. Neurol. 55, 329-341. doi: 10.1097/00005072-199603000-00008

Blümcke, I., Beck, H., Suter, B., Hoffmann, D., Fodisch, H. J., Wolf, H. K., et al. (1999). An increase of hippocampal calretinin-immunoreactive neurons correlates with early febrile seizures in temporal lobe epilepsy. Acta Neuropathol. 97, 31-39. doi: 10.1007/s004010050952

Bokor, H., Csáki, A., Kocsis, K., and Kiss, J. (2002). Cellular architecture of the nucleus reuniens thalami and its putative aspartatergic/glutamatergic projection to the hippocampus and medial septum in the rat. Eur. J. Neurosci. 16, 12271239. doi: 10.1046/j.1460-9568.2002.02189.x

Borhegyi, Z., and Leranth, C. (1997). Distinct substance P- and calretinincontaining projections from the supramammillary area to the hippocampus in rats; a species difference between rats and monkeys. Exp. Brain Res. 115, 369374. doi: 10.1007/pl00005706

Bouilleret, V., Loup, F., Kiener, T., Marescaux, C., and Fritschy, J. M. (2000). Early loss of interneurons and delayed subunit-specific changes in GABA(A)-receptor expression in a mouse model of mesial temporal lobe epilepsy. Hippocampus 10 , 305-324. doi: 10.1002/1098-1063(2000)10:3<305::aid-hipo11>3.3.co;2-9

Brandt, M. D., Jessberger, S., Steiner, B., Kronenberg, G., Reuter, K., Bick-Sander, A., et al. (2003). Transient calretinin expression defines early postmitotic step of neuronal differentiation in adult hippocampal neurogenesis of mice. Mol. Cell. Neurosci. 24, 603-613. doi: 10.1016/s1044-7431(03)00207-0

Buckmaster, P. S., and Schwartzkroin, P. A. (1995). Physiological and morphological heterogeneity of dentate gyrus-hilus interneurons in the gerbil hippocampus in vivo. Eur. J. Neurosci. 7, 1393-1402. doi: 10.1111/j.1460-9568.1995. tb01131.x

Buhl, E. H., Halasy, K., and Somogyi, P. (1994). Diverse sources of hippocampal unitary inhibitory postsynaptic potentials and the number of synaptic release sites. Nature 368, 823-828. doi: 10.1038/368823a0

Carriero, G., Arcieri, S., Cattalini, A., Corsi, L., Gnatkovsky, V., and de Curtis, M. (2012). A guinea pig model of mesial temporal lobe epilepsy following nonconvulsive status epilepticus induced by unilateral intrahippocampal injection of kainic acid. Epilepsia 53, 1917-1927. doi: 10.1111/j.1528-1167.2012.03669.x

Chamberland, S., Salesse, C., Topolnik, D., and Topolnik, L. (2010). Synapsespecific inhibitory control of hippocampal feedback inhibitory circuit. Front. Cell. Neurosci. 4:130. doi: 10.3389/fncel.2010.00130

Cobos, I., Calcagnotto, M. E., Vilaythong, A. J., Thwin, M. T., Noebels, J. L., Baraban, S. C., et al. (2005). Mice lacking Dlx1 show subtype-specific loss of interneurons, reduced inhibition and epilepsy. Nat. Neurosci. 8, 1059-1068. doi: 10.1038/nn1499

Cossart, R., Dinocourt, C., Hirsch, J. C., Merchan-Perez, A., De Felipe, J., Ben-Ari, Y., et al. (2001). Dendritic but not somatic GABAergic inhibition is decreased in experimental epilepsy. Nat. Neurosci. 4, 52-62. doi: 10.1038/82900

Curia, G., Longo, D., Biagini, G., Jones, R. S., and Avoli, M. (2008). The pilocarpine model of temporal lobe epilepsy. J. Neurosci. Methods 172, 143-157. doi: 10. 1016/j.jneumeth.2008.04.019

Davenport, C. J., Brown, W. J., and Babb, T. L. (1990a). GABAergic neurons are spared after intrahippocampal kainate in the rat. Epilepsy Res. 5, 28-42. doi: 10. 1016/0920-1211(90)90063-2

Davenport, C. J., Brown, W. J., and Babb, T. L. (1990b). Sprouting of GABAergic and mossy fiber axons in dentate gyrus following intrahippocampal kainate in the rat. Exp. Neurol. 109, 180-190. doi: 10.1016/0014-4886(90)90072-z

de Lanerolle, N. C., Kim, J. H., Robbins, R. J., and Spencer, D. D. (1989). Hippocampal interneuron loss and plasticity in human temporal lobe epilepsy. Brain Res. 495, 387-395. doi: 10.1016/0006-8993(89)90234-5 
de Lanerolle, N. C., Sloviter, R. S., Kim, J. H., Robbins, R. J., and Spencer, D. D. (1988). Evidence for hippocampal interneuron loss in human temporal lobe epilepsy. Epilepsia 29, 674.

Domínguez, M. I., Blasco-Ibáñez, J. M., Crespo, C., Marqués-Marí, A. I., and Martinez-Guijarro, F. J. (2003). Calretinin/PSA-NCAM immunoreactive granule cells after hippocampal damage produced by kainic acid and DEDTC treatment in mouse. Brain Res. 966, 206-217. doi: 10.1016/s0006-8993(02)04164-1

Drexel, M., Preidt, A. P., Kirchmair, E., and Sperk, G. (2011). Parvalbumin interneurons and calretinin fibers arising from the thalamic nucleus reuniens degenerate in the subiculum after kainic acid-induced seizures. Neuroscience 189, 316-329. doi: 10.1016/j.neuroscience.2011.05.021

El-Hassar, L., Milh, M., Wendling, F., Ferrand, N., Esclapez, M., and Bernard, C. (2007). Cell domain-dependent changes in the glutamatergic and GABAergic drives during epileptogenesis in the rat CA1 region. J. Physiol. 578, 193-211. doi: 10.1113/jphysiol.2006.119297

Emson, P. C., Rehfeld, J. F., and Rossor, M. N. (1982). Distribution of cholecystokinin-like peptides in the human-brain. J. Neurochem. 38, 1177-1179. doi: 10.1111/j.1471-4159.1982.tb05369.x

Esclapez, M., Hirsch, J. C., Ben-Ari, Y., and Bernard, C. (1999). Newly formed excitatory pathways provide a substrate for hyperexcitability in experimental temporal lobe epilepsy. J. Comp. Neurol. 408, 449-460. doi: 10.1002/(sici)10969861(19990614)408:4<449::aid-cnel>3.0.co;2-r

Faas, G. C., Schwaller, B., Vergara, J. L., and Mody, I. (2007). Resolving the fast kinetics of cooperative binding: Ca2+ buffering by calretinin. PLoS Biol. 5:e311. doi: 10.1371/journal.pbio.0050311

Fabene, P. F., Correia, L., Carvalho, R. A., Cavalheiro, E. A., and Bentivoglio, M. (2001). The spiny rat Proechimys guyannensis as model of resistance to epilepsy: chemical characterization of hippocampal cell populations and pilocarpine-induced changes. Neuroscience 104, 979-1002. doi: 10.1016/s03064522(01)00138-5

Fortin, M., Asselin, M. C., and Parent, A. (1996). Calretinin immunoreactivity in the thalamus of the squirrel monkey. J. Chem. Neuroanat. 10, 101-117. doi: 10. 1016/0891-0618(96)00109-3

Freund, T. F., and Buzsáki, G. (1996). Interneurons of the hippocampus. Hippocampus 6, 347-470. doi: 10.1002/(sici) 1098-1063(1996)6:4<347::aid-hipol>3.0. co; 2 -i

Freund, T. F., and Maglóczky, Z. (1993). Early degeneration of calretinin-containing neurons in the rat hippocampus after ischemia. Neuroscience 56, 581-596. doi: 10.1016/0306-4522(93)90358-m

Fujise, N., Liu, Y., Hori, N., and Kosaka, T. (1998). Distribution of calretinin immunoreactivity in the mouse dentate gyrus: II. Mossy cells, with special reference to their dorsoventral difference in calretinin immunoreactivity. $\mathrm{Neu}$ roscience 82, 181-200. doi: 10.1016/s0306-4522(97)00261-3

Fukuda, T., and Kosaka, T. (2000). Gap junctions linking the dendritic network of GABAergic interneurons in the hippocampus. J. Neurosci. 20, 1519-1528.

Galarreta, M., and Hestrin, S. (1999). A network of fast-spiking cells in the neocortex connected by electrical synapses. Nature 402, 72-75. doi: 10.1038/47029

Gibson, J. R., Beierlein, M., and Connors, B. W. (1999). Two networks of electrically coupled inhibitory neurons in neocortex. Nature 402, 75-79. doi: 10 $1038 / 47035$

Gulyás, A. I., Hájos, N., and Freund, T. F. (1996). Interneurons containing calretinin are specialized to control other interneurons in the rat hippocampus. J. Neurosci. $16,3397-3411$

Gulyás, A. I., Miettinen, R., Jacobowitz, D. M., and Freund, T. F. (1992). Calretinin is present in non-pyramidal cells of the rat hippocampus-I. A new type of neuron specifically associated with the mossy fibre system. Neuroscience $48,1-$ 27. doi: 10.1016/0306-4522(92)90334-x

Gulyás, A. I., Miles, R., Hájos, N., and Freund, T. F. (1993). Precision and variability in postsynaptic target selection of inhibitory cells in the hippocampal CA3 region. Eur. J. Neurosci. 5, 1729-1751. doi: 10.1111/j.1460-9568.1993. tb00240.x

Haas, C. A., Dudeck, O., Kirsch, M., Huszka, C., Kann, G., Pollak, S., et al. (2002). Role for reelin in the development of granule cell dispersion in temporal lobe epilepsy. J. Neurosci. 22, 5797-5802.

Hajos, N., Acsady, L., and Freund, T. F. (1996). Target selectivity and neurochemical characteristics of VIP-immunoreactive interneurons in the rat dentate gyrus. Eur. J. Neurosci. 8, 1415-1431. doi: 10.1111/j.1460-9568.1996.tb01604.x

Halasy, K., Buhl, E. H., Lorinczi, Z., Tamas, G., and Somogyi, P. (1996). Synaptic target selectivity and input of GABAergic basket and bistratified interneurons in the CA1 area of the rat hippocampus. Hippocampus 6, 306-329. doi: 10. 1002/(sici) 1098-1063(1996)6:3<306::aid-hipo8>3.0.co;2-k

Han, Z. S., Buhl, E. H., Lorinczi, Z., and Somogyi, P. (1993). A high degree of spatial selectivity in the axonal and dendritic domains of physiologically identified local-circuit neurons in the dentate gyrus of the rat hippocampus. Eur. J. Neurosci. 5, 395-410. doi: 10.1111/j.1460-9568.1993.tb00507.x

Handelmann, G., Meyer, D. K., Beinfeld, M. C., and Oertel, W. H. (1981). CCKcontaining terminals in the hippocampus are derived from intrinsic neurons: an immunohistochemical and radioimmunological study. Brain Res. 224, 180-184. doi: 10.1016/0006-8993(81)91130-6

Hester, M. S., and Danzer, S. C. (2013). Accumulation of abnormal adult-generated hippocampal granule cells predicts seizure frequency and severity. J. Neurosci. 33, 8926-8936. doi: 10.1523/jneurosci.5161-12.2013

Hipólito-Reis, J., Pereira, P. A., Andrade, J. P., and Cardoso, A. (2013). Prolonged protein deprivation differentially affects calretinin- and parvalbumincontaining interneurons in the hippocampal dentate gyrus of adult rats. Neurosci. Lett. 555, 154-158. doi: 10.1016/j.neulet.2013.09.036

Holmes, W. R., and Levy, W. B. (1997). Quantifying the role of inhibition in associative long-term potentiation in dentate granule cells with computational models. J. Neurophysiol. 78, 103-116.

Houser, C. R. (1991). GABA neurons in seizure disorders: a review of immunocytochemical studies. Neurochem. Res. 16, 295-308. doi: 10.1007/bf0096 6093

Houser, C. R., Miyashiro, J. E., Swartz, B. E., Walsh, G. O., Rich, J. R., and DelgadoEscueta, A. V. (1990). Altered patterns of dynorphin immunoreactivity suggest mossy fiber reorganization in human hippocampal epilepsy. J. Neurosci. 10, 267-282.

Huusko, N., Römer, C., Ndode-Ekäne, X. E., Lukasiuk, K., and Pitkanen, A. (2013). Loss of hippocampal interneurons and epileptogenesis: a comparison of two animal models of acquired epilepsy. Brain Struct. Funct. doi: 10.1007/s00429013-0644-1. [Epub ahead of print].

Jacobowitz, D. M., and Winsky, L. (1991). Immunocytochemical localization of calretinin in the forebrain of the rat. J. Comp. Neurol. 304, 198-218. doi: 10. 1002/cne.903040205

Johansen, F. F., Tønder, N., Zimmer, J., Baimbridge, K. G., and Diemer, N. H. (1990). Short-term changes of parvalbumin and calbindin immunoreactivity in the rat hippocampus following cerebral ischemia. Neurosci. Lett. 120, 171-174. doi: 10.1016/0304-3940(90)90030-d

Katsumaru, H., Kosaka, T., Heizmann, C. W., and Hama, K. (1988). Immunocytochemical study of GABAergic neurons containing the calcium-binding protein parvalbumin in the rat hippocampus. Exp. Brain Res. 72, 347-362. doi: 10. 1007/bf00250256

Kawaguchi, Y., and Hama, K. (1988). Physiological heterogeneity of nonpyramidal cells in rat hippocampal CA1 region. Exp. Brain Res. 72, 494-502. doi: 10. 1007/bf00250594

Kim, J. E., Kwak, S. E., Choi, H. C., Song, H. K., Kim, Y. I., Jo, S. M., et al. (2008). Voltage-gated $\mathrm{Na}+$ channel II immunoreactivity is selectively up-regulated in hippocampal interneurons of seizure sensitive gerbils. Neurosci. Lett. 438, 295 299. doi: 10.1016/j.neulet.2008.04.079

Kosaka, T., and Hama, K. (1985). Gap junctions between non-pyramidal cell dendrites in the rat hippocampus (CA1 and CA3 regions): a combined Golgielectron microscopy study. J. Comp. Neurol. 231, 150-161. doi: 10.1002/cne. 902310203

Kosaka, T., Katsumaru, H., Hama, K., Wu, J. Y., and Heizmann, C. W. (1987). GABAergic neurons containing the Ca2+-binding protein parvalbumin in the rat hippocampus and dentate gyrus. Brain Res. 419, 119-130. doi: 10.1016/00068993(87)90575-0

Kosaka, T., Kosaka, K., Tateishi, K., Hamaoka, Y., Yanaihara, N., Wu, J. Y., et al. (1985). GABAergic neurons containing CCK-8-like and/or VIP-like immunoreactivities in the rat hippocampus and dentate gyrus. J. Comp. Neurol. 239, 420430. doi: $10.1002 / \mathrm{cne} .902390408$

Kralic, J. E., Ledergerber, D. A., and Fritschy, J. M. (2005). Disruption of the neurogenic potential of the dentate gyrus in a mouse model of temporal lobe epilepsy with focal seizures. Eur. J. Neurosci. 22, 1916-1927. doi: 10.1111/j.14609568.2005.04386.x

Kuruba, R., Hattiangady, B., Parihar, V. K., Shuai, B., and Shetty, A. K. (2011). Differential susceptibility of interneurons expressing neuropeptide $Y$ or parvalbumin in the aged hippocampus to acute seizure activity. PLoS One 6:e24493. doi: 10.1371/journal.pone.0024493 
Lehmann, T. N., Gabriel, S., Eilers, A., Njunting, M., Kovacs, R., Schulze, K., et al. (2001). Fluorescent tracer in pilocarpine-treated rats shows widespread aberrant hippocampal neuronal connectivity. Eur. J. Neurosci. 14, 83-95. doi: 10.1046/j. 0953-816x.2001.01632.x

Lehmann, T. N., Gabriel, S., Kovacs, R., Eilers, A., Kivi, A., Schulze, K., et al. (2000). Alterations of neuronal connectivity in area CAl of hippocampal slices from temporal lobe epilepsy patients and from pilocarpine-treated epileptic rats. Epilepsia 41, S190-S194. doi: 10.1111/j.1528-1157.2000.tb01580.x

Li, X. G., Somogyi, P., Tepper, J. M., and Buzsaki, G. (1992). Axonal and dendritic arborization of an intracellularly labeled chandelier cell in the CA1 region of rat hippocampus. Exp. Brain Res. 90, 519-525. doi: 10.1007/bf00230934

Liu, Y., Fujise, N., and Kosaka, T. (1996). Distribution of calretinin immunoreactivity in the mouse dentate gyrus. I. General description. Exp. Brain Res. 108, 389-403. doi: 10.1007/bf00227262

Magloczky, Z. (2010). Sprouting in human temporal lobe epilepsy: excitatory pathways and axons of interneurons. Epilepsy Res. 89, 52-59. doi: 10.1016/j. eplepsyres.2010.01.002

Maglóczky, Z., Acsády, L., and Freund, T. F. (1994). Principal cells are the postsynaptic targets of supramammillary afferents in the hippocampus of the rat. Hippocampus 4, 322-334. doi: 10.1002/hipo.450040316

Magloczky, Z., and Freund, T. F. (1993). Selective neuronal death in the contralateral hippocampus following unilateral kainate injections into the CA3 subfield. Neuroscience 56, 317-335. doi: 10.1016/0306-4522(93)90334-c

Maglóczky, Z., and Freund, T. F. (1995). Delayed cell death in the contralateral hippocampus following kainate injection into the CA3 subfield. Neuroscience 66, 847-860. doi: 10.1016/0306-4522(94)00613-a

Maglóczky, Z., and Freund, T. F. (2005). Impaired and repaired inhibitory circuits in the epileptic human hippocampus. Trends Neurosci. 28, 334-340. doi: 10. 1016/j.tins.2005.04.002

Maglóczky, Z., Wittner, L., Borhegyi, Z., Halász, P., Vajda, J., Czirják, S., et al. (2000). Changes in the distribution and connectivity of interneurons in the epileptic human dentate gyrus. Neuroscience 96, 7-25. doi: 10.1016/s03064522(99)00474-1

Martin, L. J. (2001). Neuronal cell death in nervous system development, disease and injury (Review). Int. J. Mol. Med. 7, 455-478. doi: 10.3892/ijmm.7.5.455

Marx, M., Haas, C. A., and Häussler, U. (2013). Differential vulnerability of interneurons in the epileptic hippocampus. Front. Cell. Neurosci. 7:167. doi: 10. 3389/fncel.2013.00167

Mathern, G. W., Babb, T. L., Pretorius, J. K., and Leite, J. P. (1995). Reactive synaptogenesis and neuron densities for neuropeptide $\mathrm{Y}$, somatostatin and glutamate decarboxylase immunoreactivity in the epileptogenic human fascia dentata. J. Neurosci. 15, 3990-4004.

Mátyás, F., Freund, T. F., and Gulyás, A. I. (2004). Immunocytochemically defined interneuron populations in the hippocampus of mouse strains used in transgenic technology. Hippocampus 14, 460-481. doi: 10.1002/hipo.10191

Meskenaite, V. (1997). Calretinin-immunoreactive local circuit neurons in area 17 of the cynomolgus monkey, Macaca fascicularis. J. Comp. Neurol. 379, 113-132. doi: 10.1002/(sici) 1096-9861(19970303)379:1 < 113::aid-cne8>3.0.co;2-7

Miettinen, R., Gulyás, A. I., Baimbridge, K. G., Jacobowitz, D. M., and Freund, T. F. (1992). Calretinin is present in non-pyramidal cells of the rat hippocampus-II. Co-existence with other calcium binding proteins and GABA. Neuroscience 48, 29-43. doi: 10.1016/0306-4522(92)90335-y

Miles, R., Tóth, K., Gulyás, A. I., Hájos, N., and Freund, T. F. (1996). Differences between somatic and dendritic inhibition in the hippocampus. Neuron 16, 815823. doi: 10.1016/s0896-6273(00)80101-4

Mitchell, J., Gatherer, M., and Sundstrom, L. E. (1995). Loss of hilar somatostatin neurons following tetanus toxin-induced seizures. Acta Neuropathol. 89, 425430. doi: $10.1007 / \mathrm{bf} 00307647$

Murakawa, R., and Kosaka, T. (1999). Diversity of the calretinin immunoreactivity in the dentate gyrus of gerbils, hamsters, guinea pigs and laboratory shrews. J. Comp. Neurol. 411, 413-430. doi: 10.1002/(sici)10969861(19990830)411:3<413::aid-cne5>3.3.co;2-h

Muzzi, P., Camera, P., Di Cunto, F., and Vercelli, A. (2009). Deletion of the citron kinase gene selectively affects the number and distribution of interneurons in barrelfield cortex. J. Comp. Neurol. 513, 249-264. doi: 10.1002/cne.21927

Nitsch, R., and Léránth, C. (1993). Calretinin immunoreactivity in the monkey hippocampal formation. II: intrinsic GABAergic and hypothalamic nonGABAergic systems. An experimental tracing and coexistence study. Neuroscience 55, 797812. doi: $10.1016 / 0306-4522(93) 90442-\mathrm{i}$
Nitsch, R., and Ohm, T. G. (1995). Calretinin immunoreactive structures in the human hippocampal formation. J. Comp. Neurol. 360, 475-487. doi: 10. 1002/cne.903600309

Perez, Y., Morin, F., Beaulieu, C., and Lacaille, J. C. (1996). Axonal sprouting of CA1 pyramidal cells in hyperexcitable hippocampal slices of kainate-treated rats. Eur. J. Neurosci. 8, 736-748. doi: 10.1111/j.1460-9568.1996.tb01259.x

Pitkanen, A., Schwartzkroin, P. A., and Moshe, S. L. (2006). Models of Seizures and Epilepsy. London: Elsevier Academic Press.

Represa, A., Tremblay, E., and Ben-Ari, Y. (1990). Sprouting of mossy fibers in the hippocampus of epileptic human and rat. Adv. Exp. Med. Biol. 268, 419-424. doi: 10.1007/978-1-4684-5769-8_46

Ribak, C. E., Seress, L., and Leranth, C. (1993). Electron microscopic immunocytochemical study of the distribution of parvalbumin-containing neurons and axon terminals in the primate dentate gyrus and Ammon's horn. J. Comp. Neurol. 327, 298-321. doi: 10.1002/cne.903270211

Rogers, J. H. (1987). Calretinin: a gene for a novel calcium-binding protein expressed principally in neurons. J. Cell Biol. 105, 1343-1353. doi: 10.1083/jcb. 105.3.1343

Rogers, J. H., and Resibois, A. (1992). Calretinin and calbindin-d28k in rat brainpatterns of partial co-localization. Neuroscience 51, 843-865. doi: 10.1016/03064522(92)90525-7

Seress, L., Abrahám, H., Czéh, B., Fuchs, E., and Léránth, C. (2008). Calretinin expression in hilar mossy cells of the hippocampal dentate gyrus of nonhuman primates and humans. Hippocampus 18, 425-434. doi: 10.1002/hipo. 20403

Seress, L., Gulyas, A. I., Ferrer, I., Tunon, T., Soriano, E., and Freund, T. F. (1993a). Distribution, morphological features and synaptic connections of parvalbuminand calbindin D28k-immunoreactive neurons in the human hippocampal formation. J. Comp. Neurol. 337, 208-230. doi: 10.1002/cne.903370204

Seress, L., Gulyás, A. I., and Freund, T. F. (1991). Parvalbumin- and calbindin D28k-immunoreactive neurons in the hippocampal formation of the macaque monkey. J. Comp. Neurol. 313, 162-177. doi: 10.1002/cne.903130112

Seress, L., Nitsch, R., and Leranth, C. (1993b). Calretinin immunoreactivity in the monkey hippocampal formation-I. Light and electron microscopic characteristics and co-localization with other calcium-binding proteins. Neuroscience 55, 775-796. doi: 10.1016/0306-4522(93)90441-h

Sharma, A. K., Reams, R. Y., Jordan, W. H., Miller, M. A., Thacker, H. L., and Snyder, P. W. (2007). Mesial temporal lobe epilepsy: pathogenesis, induced rodent models and lesions. Toxicol. Pathol. 35, 984-999. doi: 10. 1080/01926230701748305

Sik, A., Penttonen, M., and Buzsaki, G. (1997). Interneurons in the hippocampal dentate gyrus: an in vivo intracellular study. Eur. J. Neurosci. 9, 573-588. doi: 10. 1111/j.1460-9568.1997.tb01634.x

Sik, A., Penttonen, M., Ylinen, A., and Buzsáki, G. (1995). Hippocampal CA1 interneurons: an in vivo intracellular labeling study. J. Neurosci. 15, 6651-6665.

Sik, A., Ylinen, A., Penttonen, M., and Buzsaki, G. (1994). Inhibitory CA1-CA3hilar region feedback in the hippocampus. Science 265, 1722-1724. doi: 10. 1126/science. 8085161

Slézia, A., Kékesi, A. K., Szikra, T., Papp, A. M., Nagy, K., Szente, M., et al. (2004). Uridine release during aminopyridine-induced epilepsy. Neurobiol. Dis. 16, 490499. doi: 10.1016/j.nbd.2004.02.011

Sloviter, R. S. (1994). On the relationship between neuropathology and pathophysiology in the epileptic hippocampus of humans and experimental animals. Hippocampus 4, 250-253. doi: 10.1002/hipo.450040304

Sloviter, R. S. (1996). Hippocampal pathology and pathophysiology in temporal lobe epilepsy. Neurologia 11(Suppl. 4), 29-32.

Sloviter, R. S. (1999). Status epilepticus-induced neuronal injury and network reorganization. Epilepsia 40, S34-39; discussion S40-S31. doi: 10.1111/j.15281157.1999.tb00876.x

Sloviter, R. S., Sollas, A. L., Barbaro, N. M., and Laxer, K. D. (1991). Calciumbinding protein (calbindin-D28K) and parvalbumin immunocytochemistry in the normal and epileptic human hippocampus. J. Comp. Neurol. 308, 381-396. doi: 10.1002/cne.903080306

Somogyi, P., Nunzi, M. G., Gorio, A., and Smith, A. D. (1983). A new type of specific interneuron in the monkey hippocampus forming synapses exclusively with the axon initial segments of pyramidal cells. Brain Res. 259, 137-142. doi: 10. 1016/0006-8993(83)91076-4

Sperk, G., Marksteiner, J., Gruber, B., Bellmann, R., Mahata, M., and Ortler, M. (1992). Functional changes in neuropeptide Y- and somatostatin-containing 
neurons induced by limbic seizures in the rat. Neuroscience 50, 831-846. doi: 10 . 1016/0306-4522(92)90207-i

Sundstrom, L. E., Brana, C., Gatherer, M., Mepham, J., and Rougier, A. (2001). Somatostatin- and neuropeptide Y-synthesizing neurones in the fascia dentata of humans with temporal lobe epilepsy. Brain 124, 688-697. doi: 10. 1093/brain/124.4.688

Tang, F. R., Chia, S. C., Jiang, F. L., Ma, D. L., Chen, P. M., and Tang, Y. C. (2006). Calcium binding protein containing neurons in the gliotic mouse hippocampus with special reference to their afferents from the medial septum and the entorhinal cortex. Neuroscience 140, 1467-1479. doi: 10.1016/j.neuroscience. 2006.03.022

Tang, F. R., and Loke, W. K. (2010). Cyto-, axo- and dendro-architectonic changes of neurons in the limbic system in the mouse pilocarpine model of temporal lobe epilepsy. Epilepsy Res. 89, 43-51. doi: 10.1016/j.eplepsyres.2009.10.015

Thom, M., Sisodiya, S. M., Beckett, A., Martinian, L., Lin, W. R., Harkness, W., et al. (2002). Cytoarchitectural abnormalities in hippocampal sclerosis. J. Neuropathol. Exp. Neurol. 61, 510-519.

Tóth, K., Eross, L., Vajda, J., Halász, P., Freund, T. F., and Maglóczky, Z. (2010). Loss and reorganization of calretinin-containing interneurons in the epileptic human hippocampus. Brain 133, 2763-2777. doi: 10.1093/brain/awq149

Tyan, L., Chamberland, S., Magnin, E., Camire, O., Francavilla, R., David, L. S., et al. (2014). Dendritic inhibition provided by interneuron-specific cells controls the firing rate and timing of the hippocampal feedback inhibitory circuitry. $J$. Neurosci. 34, 4534-4547. doi: 10.1523/jneurosci.3813-13.2014

Urbán, Z., Maglóczky, Z., and Freund, T. F. (2002). Calretinin-containing interneurons innervate both principal cells and interneurons in the CA1 region of the human hippocampus. Acta Biol. Hung. 53, 205-220. doi: 10.1556/abiol.53.2002. $1-2.19$

van Vliet, E. A., Aronica, E., Tolner, E. A., Lopes da Silva, F. H., and Gorter, J. A. (2004). Progression of temporal lobe epilepsy in the rat is associated with immunocytochemical changes in inhibitory interneurons in specific regions of the hippocampal formation. Exp. Neurol. 187, 367-379. doi: 10.1016/j. expneurol.2004.01.016

Wittner, L., Eross, L., Czirják, S., Halász, P., Freund, T. F., and Maglóczky, Z. (2005). Surviving CAl pyramidal cells receive intact perisomatic inhibitory input in the human epileptic hippocampus. Brain 128, 138-152. doi: 10.1093/brain/ awh339

Wittner, L., Eross, L., Szabó, Z., Tóth, S., Czirjak, S., Halász, P., et al. (2002). Synaptic reorganization of calbindin-positive neurons in the human hippocampal CA1 region in temporal lobe epilepsy. Neuroscience 115, 961-978. doi: 10. 1016/s0306-4522(02)00264-6

Wittner, L., Maglóczky, Z., Borhegyi, Z., Halász, P., Tóth, S., Eross, L., et al. (2001). Preservation of perisomatic inhibitory input of granule cells in the epileptic human dentate gyrus. Neuroscience 108, 587-600. doi: 10.1016/s03064522(01)00446-8

Wu, J., Ma, D. L., Ling, E. A., and Tang, F. R. (2012). Corticotropin releasing factor (CRF) in the hippocampus of the mouse pilocarpine model of status epilepticus. Neurosci. Lett. 512, 83-88. doi: 10.1016/j.neulet.2012.01.057

Zhang, S., Khanna, S., and Tang, F. R. (2009). Patterns of hippocampal neuronal loss and axon reorganization of the dentate gyrus in the mouse pilocarpine model of temporal lobe epilepsy. J. Neurosci. Res. 87, 1135-1149. doi: 10.1002/jnr.21941

Zhao, C., Deng, W., and Gage, F. H. (2008). Mechanisms and functional implications of adult neurogenesis. Cell 132, 645-660. doi: 10.1016/j.cell.2008.01.033

Conflict of Interest Statement: The authors declare that the research was conducted in the absence of any commercial or financial relationships that could be construed as a potential conflict of interest.

Received: 05 June 2014; accepted: 04 September 2014; published online: 29 September 2014

Citation: Tóth K and Maglóczky Z (2014) The vulnerability of calretinin-containing hippocampal interneurons to temporal lobe epilepsy. Front. Neuroanat. 8:100. doi: 10.3389/fnana.2014.00100

This article was submitted to the journal Frontiers in Neuroanatomy.

Copyright $\odot 2014$ Tóth and Maglóczky. This is an open-access article distributed under the terms of the Creative Commons Attribution License (CC BY). The use, distribution or reproduction in other forums is permitted, provided the original author(s) or licensor are credited and that the original publication in this journal is cited, in accordance with accepted academic practice. No use, distribution or reproduction is permitted which does not comply with these terms. 